\title{
Everyday Nationalism and Making Identity Count
}

\author{
Ted Hopf (NUS) and Srdjan Vucetic (uOttawa)
}

Paper prepared for the CEEISA-ISA Joint International Conference June 17th - 19th, 2019, Belgrade, Serbia

23 May 2019 draft (8,600 words, 62 footnotes, 1 Table, 1 Figure)

[abstract] The literature on "everyday nationalism" foregrounds constructivist practice theory as well as interpretivist methodologies. Our project "Making Identity Count" does something similar but with an aim to advance the study of International Relations (IR) rather than the study of nationalism. Here we suggest that these two approaches are basically complementary, and that a theoretical and methodological cross-fertilization between them has a real potential to yield new insights in both fields.

National Identity + Everyday Nationalism + Interpretivism + Constructivism

A growing literature on "everyday nationalism" (EN) promises to add value to the social constructivist study of nationalism and ethno-nationalism by foregrounding practices as well as interpretivist methodologies. "Making Identity Count" (MIC) makes a similar promise in International Relations (IR): it sets out to generate the field's first constructivist national identity database. ${ }^{1}$ This database is being assembled inductively from everyday texts such as newspapers, novels and movies. So, rather than relying on surveys or popular following a codebook filled with pre-given ideas about Chinese or French identity, analysts allow identity categories to emerge directly before they move to reconstruct what it means to be China or France. Analysists also count the number of times a particular category appears in the text in order to establish relative salience. This then opens the door for quantifying the findings and thus contributing to quantitatively oriented scholarship on national identity in IR and beyond.

We make two propositions in this paper: that EN and MIC are complementary, and that a theoretical and methodological cross-fertilization between these two approaches could help advance the study of nations, nationalism, and national identity. We begin by outlining EN and then quickly move on to introduce MIC. There, we offer a novel reading of Antonio Gramsci as a constructivist interested in the everyday experiences of nation and national identity, followed by an illustration of the project's methodology drawn from our current research on postwar Britain. By bringing forth the masses and their practices, our Gramsci-inspired project follows the scholarship on EN not only ontologically and conceptually, but also in terms of substantive interest in variegated relations and processes through which nations become themselves. We end with a discussion of what these two approaches can borrow from each other, and why.

\footnotetext{
${ }^{1}$ See Hopf and Allan, eds., 2016, and the project website: https://www.makingidentitycount.org/
} 
A brief reflection on the semantic field that encompasses the words "nationalism" and "national identity" is necessary at the outset. Our starting point is that nations and its cognates are associated with modernity. ${ }^{2}$ As these processes are highly context-dependent, scholars often add adjectives to their categories. The term nationalism thus often includes qualifiersdiachronic (e.g., postcolonial), geographic (e.g., Balkan) or typological (e.g., civic). ${ }^{3}$ Another axiom is that these categories refer to social and relational phenomena- "negotiated practice" - as opposed to ontological "things." This is evident in the now standard claim that national identity requires difference to be, which is also to say that national identification practices depend on the construction of various Others. ${ }^{4}$

\section{Gramsci the Constructivist}

Constructivist scholarship on nationalism began as a study of state-directed nation making - that is, of the role of political elites and political institutions in constructing nations and national identities, which is an approach best captured by the concept of political construction. ${ }^{5}$ From W.E.B. Du Bois and Benoy Kumar Sarkar to Ernest Gellner and many others, this work has taught us that there are always competing versions of the nation at work, each of which offers different combinations of aesthetic, intellectual, ideological, historical, geographical, religious, social, and political elements. ${ }^{6}$ Today's constructivists are just as likely to focuses on mass agency, however - that is, it explores not only how the masses respond to elite manipulation/cues but also how the masses elaborate, (re)produce, or challenge national identity categories as well as so nations themselves.

EN is an outstanding example of the latter approach. Arising in the 1990s with new Bourdieusian readings of nationhood as well as with Michael Billig's influential work on "banal nationalism," EN came to distinguish itself by focusing on the routine, taken-for-granted habits and symbols of social life that lie beyond the authority, attention, or culture of politicians, government mandarins and other establishment figures. ${ }^{7}$ J. Paul Goode and David Stroup's programmatic statement on EN explains why this focus remains valuable:

1) it allows constructivists to steer clear of the twin pitfalls of essentialism and reification and stay true to their intersubjectivist ontology;

2 ) it enables new accounts of "how the vast majority of people conceive of, and interact with, ethnic or national identities";

\footnotetext{
2 Malešević 2013.

3 Todorova 2015.

${ }^{4}$ And Others are sometimes historical Selves. Wæver 1996. On the pro et contra of "national identity" versus "nationalism" in sociology, see, respectively, McCrone and Bechhofer 2015 and Malešević 2013. For political science debates on the same, see Abdelal et al 2009 and Alemán and Woods 2017.

${ }^{5}$ Smith 2015.

${ }^{6}$ On Du Bois' and Sarkar's constructivist ideas about nationhood, see, respectively, Rabaka 2009 and Goswami 2012. On Gellner and other classics of nationalism studies, see Skey 2011: 149-152 and Malešević 2013: 58-64.

${ }^{7}$ Brubaker 1992 and Bilig 1995.
} 
3) it links the above to "large-scale social and political processes, such as the sources of authoritarian legitimacy or the ethnicization of economic development";

4) it provides new insight into "the repertoires available to elites" and also "why citizens respond to certain varieties of ethnic cues rather than others (religious, educational)"; 5 ) it facilitates novel cross-case comparisons since it helps us observe gaps and overlaps in ethnic vs nonethnic, market vs nonmarket or domestic vs transnational practices (to use but three binaries circulating in the literature on nationhood and ethnicity); and 6 ) it enables new accounts of how identities change. ${ }^{8}$

Much of present-day EN scholarship is rooted in practice theory and in particular the concepts of "habitus" and "doxa" with which Pierre Bourdieu sought to capture the fact together many if not most contexts people tend to carry their social lives unconsciously and unreflexively - that is, according to embodied practices, routines and habits. ${ }^{9}$ Same insights have originally inspired our conceptualization of national identity. ${ }^{10}$ However, one of the main theoretical inspirations for our MIC project is Gramsci, and in particular is writings on social order and change through hegemony its challengers. ${ }^{11}$ We now think that our neo-Gramscian framework could be profitably used in EN as well. ${ }^{12}$ For one, the Italian philosopher is invaluable in theorizing the relationship between elite national identity projects and mass conceptions of what it means to be a member of a particular national community. Additionally, he developed a theory of hegemony that combines elite ideology with mass common sense, which is enormously useful for EN given that both of these levels of national identity cultivation, production, and reproduction are necessary to understand how national identities are propagated from above, and (re)constituted from below.

To begin with, Gramsci's understanding of social reality is consistent with constructivism's intersubjectivist ontology. ${ }^{13}$ In elaborating historical materialism, he indeed rejects race, skin color, the state of nature, and the idea that "man is the country he lives in." Instead "that human nature is the ensemble of social relations is most satisfying, because it includes the idea of becoming--man becomes, he changes continuously, with the changing of social relations." Identities are necessarily relational: "Man is aristocratic insofar as man is a serf." 14 It is this "historically defined consciousness that indicates what is natural and what is

\footnotetext{
${ }^{8}$ Goode and Stroup 2015 offer a programmatic statement. For a literature reviews, see Knott 2016 and Ichijo 2016.

${ }^{9}$ See, for example, Skey 2011: 14. Note Billig's interest in 'the ideological habits' of nationhood (1995: 6)

10 Hopf 2002, 2010.

${ }^{11}$ Allan, Vucetic, and Hopf, 2018, Hopf 2013.

12 For some criticisms, see Morozov and Pavlova 2020. For more established neo-Gramscian approaches in IR, see Cox 1987 and Bieler, Bruff and Morton 2015.

${ }^{13}$ Our understanding of identity, and national identity, is a social constructivist conceptualization of one's sense of self being brought into being through interaction with Other/s. This interaction occurs continually and across relationships which implies that identities are always being created, are never finished, but can be effectively stabilized through daily social practices and institutionalization.

${ }^{14}$ Notebook 6, Section 35, p. 186. See also Notebook 8, Section 151, pp. 320-1. All selections from the translations of Gramsci's Prison Notebooks, Vols 1-3 (1992, 1996, 2007).
} 
not."15 Mass common sense, where the practices and ideas of day-to-day nationalism reside, is socially constructed in history and place.

Of course Gramsci's focus of attention when writing his notebooks in prison was not primarily on nationalism. On the other hand, he wrote a fair amount about the existence of fullblown "national-popular cultures" in places like France, and the absence of such a culture in Italy. In the latter, as Gramsci observed, "the people-nation was missing." 16 We could say the lack of a national identity in Italy was one of Gramsci's more frequent points of comparison of Italy with other European countries, especially France, but also Germany and Britain. In Italy, "national sentiment is of recent vintage;" it is only in "a formative phase, for literature has never been a national phenomenon, but a cosmopolitan one." ${ }^{17}$ Gramsci pointed out the necessity of having a national language if one is to have a national identity, and a national language cannot just be decreed by the state, it "can be formed only to the extent that the social life of the nation gives rise to numerous and stable contacts among various segments of the nation....through writing, trade, and commerce...." 18 Gramsci understands national identity the same as any contemporary social constructivist would: it is a product of daily discursive practices, that which is spoken and performed into being.

While not concentrating on the nationalist component of an elite ideological hegemony, Gramsci did write about hegemony as if it must include an encompassing national identity if it is to be based on consent, and not purely coercion. Hegemony is more secure and stable the more deeply the discourse of national identity being propagated by the elite resonates with the masses, still more if it becomes part of the taken for granted common sense of the broad population. ${ }^{19}$ Mass common sense, "the most widespread conception of life and morals," is the "folklore of philosophy." ${ }^{20}$ Gramsci, while contemplating the failure of socialism to come to Italy, in particular the failure of the Italian socialists to successfully recruit the poor and oppressed southern Italian peasantry, observed that common sense "must be conceived as something very serious and be taken seriously" if one wishes one's ideology to be taken up by more than a narrow stratum of fellow intellectuals. ${ }^{21}$ Gramsci asks rhetorically whether elite ideology, if it is to succeed in mobilizing the masses, "can be in opposition to the spontaneous sentiments of the masses," to its their common sense, to their "traditional popular conception of the world?" His answer is: "It cannot be in opposition." One must remember that "reality will conform to an abstract scheme." ${ }^{22}$ Instead, the national identity projects advanced by elites must resonate with mass commonsensical understandings of their own identities, national, and

\footnotetext{
15 Notebook 8, section 151, p. 321. See also Section 215, p. 365.

16 Notebook 3, Section 82, p. 81.

${ }_{17}$ Notebook 6, Section 16, p. 15. See also Notebook 6, Section 104, p. 87.

18 Notebook 3, Section 46, p. 45.

${ }^{19}$ Gramsci understandably in the case of Italy argued that religion was the major component of mass common sense, rather than national identity. Ibid. Notebook 4, Section 40, pp. 189-90. See also Notebook 8, Section 173 , pp. 333-4.

${ }^{20}$ Notebook 1, Section 65 p. 173.

${ }^{21}$ Notebook 1, Setion 89, p. 189. See also Notebook 8, section 213, p. 360 and section 220, p. 369.

${ }^{22}$ Notebook 3, Section 48, pp. 50-52.
} 
otherwise. This is a mission that is never completed. Beyond ethnonational differences that separate "Italians" from one another, there are the other salient differences of class, region, and language. Moreover, common sense is about more than national identity. The latter might not even be part of many communities of common sense in a country.

In order to find out what common senses exist in any society, Gramsci recommended comprehensive study of mass popular texts, something we pursue in our project. As we suggest next, he also provided sound methodological advice on how to best design such a study.

\section{Finding National Identity}

Upon arriving in prison, Gramsci did not immediately begin to write his notebooks. Instead, he went about identifying topics for the notebooks he expected to write, and developing a bibliography of materials he would ask others, mostly his sister, to send to him in prison. One of those topics he provisionally titled: "Serialized fiction and popular taste in literature." 23 In letters from prison, in this case to Malvina Sanna, he defended reading "trashy" popular literature, pointing out it could suggest answers to the following critical questions: "Why is this always the most read and most published literature? What needs does it satisfy? What aspirations does it respond to? What sentiments are views are represented in these awful books that have such broad appeal?"24

We think that Gramsci's interest in how the nation and how being a member of a nation is represented in "these awful books" is in line with Billig and other scholars of "banal nationalism" who argue that rather than through major sociopolitical upheavals or high-profile mediated spectacles, national identity is for the most part produced through banal practices of everyday culture. ${ }^{25}$ Gramsci argues this as well, hence his advice on how to sample "the most popular literature," ${ }^{26}$ and why: Guerin Meschino, an age-old satirical, can serve as "an enyclopedia to gather information on the mental coarseness and cultural indifference of the vast stratum of people who still feed on it." 27 Similarly, "popular serial novels" produce "an implicit national sentiment." For example, Jules Verne's fantasies produced for the French readers "an anti-English sentiment, linked to the loss of colonies and the lingering pain of naval

\footnotetext{
${ }^{23}$ Introduction, Volume 1, p. 9.

${ }^{24}$ Quoted in Introduction, pp. 15-16. Notebook 1, Section 43, p. 129.

25 Bilig 1995, Edensor 2002, Skey 2011. There is now a host of conceptual binaries in this literature: banal/hot, banal/blatant, banal/ecstatic, and banal/everyday (Skey and Antonsich, eds., 2017). We address some of them below.

${ }^{26}$ Notebook 1, Section 43, p. 129. On the importance of historical fiction for the masses, or "belletristic history," see Notebook 6, Section 10, p. 7.

27 Notebook 6, Section 207, p. 148.
} 
defeats." 28 Henrik Ibsen's A Doll's House, too, is very well-liked because it "represents sentiments and inclinations that find resonance in the popular psyche." 29

Gramsci suggested sampling "the commercial part of national-popular literature" widely, as "it is extremely valuable from point of view of the history of culture,... of the philosophy of the age, that is, of the mass of sentiments and conceptions of the world prevalent among the 'silent' multitude." ${ }^{30}$ He likewise argued for attention to the press in general, and reviews of every kind-"scientific, literary, philological, popular....even parish bulletins." 31 He also calls for reconstructing a "living historical model" of public opinion through stuff of "libraries, schools, associations and clubs of various kinds, even architecture, the layout of streets, and their names." ${ }^{2} 2$ The same goes for May Day festivals; "there must be a more or less reliable record of the subjects they treat." ${ }^{33}$ One should also survey theater and cinema, for they "have a speed and field of action enormously greater than the book," and comparable to newspapers and journals. ${ }^{34}$

In addition to calling for analytical attention to newspapers and movies, Gramsci also recommended ethnographic efforts to "obtain knowledge of popular sentiment" through "active and conscious co-participation, through 'compassionality'." 35 Together with many if not most EN scholars, we too understand textual analysis as an inferior kind of ethnography. ${ }^{36}$ Yet, we also think that at least some manifestations of everyday nationalism and national identity can be accessed and reconstructed via the interpretation of text. Our core methodological wager is straightforward: if at least some habits of nationhood discursive, then it stands to reason that one could recover them through some form of discourse analysis of a sample of texts that widely circulate in modern states. ${ }^{37}$ This harmonizes with one of the main goals in EN research: to recover the routine, unreflective ("unnoticed") ways through which nations become a presence in people's everyday lives.

MIC data comes in the form of inductively coded archives and accompanying "national identity reports" generated by human coders working with agreed-upon discourse analytic parameters. Although the project welcomes adoption of its methodology for any country, at this stage the focus is on the national identities of ten great powers for every tenth year from

\footnotetext{
${ }^{28}$ Notebook 3, Section 78, p. 77. See also pp. 121-2 on "Popular Literature." Gramsci wrote in a letter that he "possess[es] the quite fortunate capacity to find something interesting even in the lowliest of intellectual productions, such as serial novels." Quoted in Introduction, p. 13. See also Notebook 1, Section 80, p. 184.

${ }^{29}$ Notebook 3, Section 78, p. 78.

30 Notebook 5, Section 54, pp. 312-3.

${ }^{31}$ On sampling newspapers, see also Notebook 3, Section 63, p. 62, Notebook 4, Section 89, p. 259, and Notebook

1, Section 116, p. 201.

32 Notebook 3, Section 49, pp. 52-3.

${ }^{33}$ Section 63, p. 64. On historical mis/representations that become part of common sense folklore, see also Notebook 1, Section 80, p. 187.

${ }^{34}$ Notebook 1, Section 153, p. 232.

35 Notebook 2, Section 25, pp. 59-60.

${ }^{36}$ Fox and Miller-Idriss 2008, p. 556.

${ }^{37}$ Allan 2016. On alternative method/ologies for analyzing identity, see Abdelal et al 2009.
} 
1950 to the present-China, India, France, Brazil, Japan, Germany, and Italy, the UK, the US, and the USSR/Russia over the course of seven calendar years in total. A more recently established stream called "MIC in Asia" analyzes the discourses of national identity in all ASEAN members, in addition to South Korea, Taiwan, and Hong Kong. ${ }^{38}$

Each report is based on a standardized sample of texts drawn from an assortment of everyday experiences and institutional centers, namely from 1) political leadership speeches, 2) newspapers, 3) high school history textbooks, 4) novels, and 5) movies. The main rationale for accessing and analyzing such different forms and media of communication was to capture common everyday ideas, at both elite and mass levels, about what it means to be a nation or its member in a given year. As we the project goes back in time, radio broadcasts, street operas and mass poetry readings become sources of mass texts as well. By the same token, as MIC research expands into contemporary Asia, income level requires moving beyond movies and novels to more affordable cultural consumables such as TV shows, pirated DVDs, and downloaded movie videos.

\section{Table 1 about here}

Table 1 summarizes the sources used for the British national identity reports, 1950 to 2000 . They are grouped in five columns, whereby with the category "newspapers" is further divided into two subcategories. Newspapers editorials, op-eds and columns ("opinion" for short), together with leadership speeches and history textbooks are thus used as sources of elite political discourse, while letters to the editor are meant to help gauge mass discourse, together with novels and movies. For each year under study, an effort was made to select historical documents that can be credibly described as bestselling, must-read, highest-circulating, or most-watched.

For the sake of space we cannot discuss the selection of texts in each of these genres, so we will showcase two newspapers and novels. ${ }^{39}$ For the first, we followed the rankings based on the Press Council and Audit Bureau of Circulations circulation figures or the closest equivalent. Accordingly we selected Daily Express and Daily Mirror from 1950 through 1980, The Sun and Daily Mirror for 1990 and The Sun and Daily Mail in 2000. We further sampled the editions published on the $15^{\text {th }}$ day of each month, including, when appropriate, Sunday equivalents of the selected newspaper (Sunday Mirror, Sunday Express, Mail on Sunday but not News of the World). With this selection, we achieved some variance in ownership structures and ideological

\footnotetext{
${ }^{38}$ For updates on the "Making Identity Count in Asia" project, see https://ari.nus.edu.sg/Cluster/Members/CA The project's ultimate aim is to produce national identity data for dozens of countries from 1810 through the present. ${ }^{39}$ For the selection criteria, see Srdjan Vucetic, "The United Kingdom, 1950-2000-Primary Texts," 23 June 2016 , Available at https://www.makingidentitycount.org/how-to-docs/
} 
orientations of newspapers known as "popular" or "mass-market" throughout the entire period under study. ${ }^{40}$

Identifying "bestselling novels" was more challenging. To select two top-selling items on the consumer market of books bought by private individuals for their own use or as gifts in each year, we first consulted scholarly histories of the book and of UK fiction industry. Based on this knowledge, we adopted multiple strategies. For 1950 and 1960, we consulted annual round-ups of the bestseller market by W.H. Smith's Trade News, The Observer, The Bookseller, Evening Standard, Evening News, Time \& Tide, The Sunday Telegraph, and The Daily Express and picked the two British-authored novels closest to the top of each list. For 1970 and 1980, the reliability of bestseller lists improved thanks to introduction of surveys, automated data collection (after 1980) and other ranking instruments. Especially helpful were secondary assessments of said lists published in specialist magazines such as The Listener, a weekly BBC magazine published until 1991, and by journalist Alex Hamilton in The Guardian (from 1970 onwards). For 1990 and 2000, we followed the rankings generated by computerized data capture via Electronic Pointof-Sale equipment and disseminated by companies such as Nielsen BookScan. As Table 1 shows, several authors appear in multiple years: Fleming, Christie, Smith, Forsyth, and Rowling.

The paperback revolution changed our selection criteria as well since it rendered paperback the dominant format for bestsellers. First, the paperback revolution changed the meaning of high-circulating: in the late 1940s, a top hardback novel would achieve sales of 100,000 over several years, whereas in the 1990s a bestselling paperback would have 500,000 copies sold in weeks. Second, this means that some our "bestselling novels of the year" after 1960 were in fact paperback editions of a hardback released a year, two or three before the year of the study. In 1960, we thus selected lan Fleming's Dr No, released in March 1958 over Fleming's For Your Eyes Only, released in April 1960. In principle, either one would have been acceptable as UK readers en masse were enjoying multiple Fleming's Bond novels. However, Dr. No, the sixth book in the espionage adventure series, topped that year's bestseller with more than 150,000 copies old thanks to the paperback release in February as well as, to a lesser extent, due to both text and comic-strip serializations that year in Daily Express. For Your Eyes Only, in contrast, was released in hardback and sold less than 22,000 copies. The same rationale applied to 4.50 from Paddington, a novel by Agatha Christie first published in November 1957 but reappearing in paperback three years later with Fontana Books. ${ }^{41}$

\footnotetext{
${ }^{40}$ Although The Sun replaced Daily Express in 1980, we still used the latter due to some difficulties in accessing the latter's archive. This and similar deviations from MIC sampling rules are reported in each national report.

${ }^{41}$ Neither is to be confused with "the steady longterm sellers" such as the Bible, Tolkien's three-volume fantasy The Lord of the Rings (1954-5) and, arguably, George Orwell's Animal Farm (1945). In all cases we selected novels dealing with contemporary themes. To go with the year 1960 again, we were initially drawn to Lady Chatterley's Lover by D.H. Lawrence, a book that sold over 200,000 paperback copies within weeks following the infamous obscenity trial in November-October of that year. However, this was a Penguin paperback of a book published in 1928. Our runner ups included John Braine's Room at the Top (1957), which sold well thanks to a lucrative paperback-movie tie-in in 1959 and David Storey's This Sporting Life, which won the 1960 Macmillan Fiction Award, and On the Beach by Nevil Shute, a novel first published in 1957 that sold well in tens of thousands due to the author's death in 1960 and the story's cinamatization in 1959, but without quite reaching the numbers of Fleming and Christie books.
} 
As a strategy for creating an archive of texts containing information on British identity in 1950-2000, this approach has two obvious limitations. One is that England and more specifically London are taken to be the dominant sites of the discursive production of Britishness. Admittedly, this reproduces a shortcoming in Billig's own work on the "British" society. ${ }^{42}$ Sampling newspaper items appearing in, for example, Manchester Evening News or Liverpool Echo or in Scottish history textbooks would have provided a more complete picture of what it means to be Britain or British through time. Same for a less print-centric archive, not least because radio and, from 1970 onwards, television shows were at least as popular as movies.

These sampling choices were driven by both principle and pragmatism. As Tom Edensor has shown in his contribution to the EN literature, the nation is often hierarchical not simply in the sense that some places are more likely to be centers of the discursive production-Gramsci would call them the centers of 'moral and intellectual leadership'-, but also in the sense that some regions are constructed as more national or authentic than others. ${ }^{43}$ Larger samples also cost more. Adding BBC's To The Manor Born would have greatly diversified our mass sample for the year 1980 but it would also be prohibitive in terms of coding hours, especially considering the multimodal nature of discursive meanings contained therein.

\section{Figure 1 About Here}

Figure 1 visualizes the generation of national identity report as a step-by-step process (grey boxes, numbered, with notes on key definitions, assumptions, and aims in white boxes). The sampling strategy, shown as Step 3, is moving progressively from the project's constructivist "first principles" and discourse analytic methodology in, respectively, Steps 1 and 2. The sampling strategy simultaneously enables an inductivist analysis of British identity, Steps 4 through 7. Here, the research team began by putting aside any pre-fabricated ideas about what it meant to be Britain or British - as also England and English, Ireland and Irish and so on. Three basic inductive coding rules were used to code identity categories appearing in the actual texts: valence; aspirational/aversive - that is, if the identity is one that the Self aspires to or is trying to avoid; and significant Other, which refers to any broadly national categories to which the Self compares itself in time and space.

A distinct advantage of this method is that it forces coders to capture local particulars and contingent meanings that might otherwise be lost when analysis accepts either platitudes ("The British are militaristic") or, indeed, statements drawn public opinion research ("Young Britons rank Spain as top vacation destination"). The method likewise requires coders to differentiate mere themes ("leisure is good") from actual national identity categories ("the English like good leisure"), while also paying special attention to any relevant deployment of deixis, including pronouns, possessive adjectives, and locatives as well as any references to the broader

\footnotetext{
42 Skey 2009, p. 335, and Billig 201, p. 314.

${ }^{43}$ Edensor (2002).
} 
structures of belonging: "In this society..." "We have always been traders." "Our empire was essentially liberal," etc. To illustrate this procedure, consider our coding of "No Trumpets," an editorial published in Daily Express on 15 September 1960:

Where are the drums? Where are the trumpets? They do not sound for today's preliminary session of the Commonwealth economic conference.

The sad truth is that nothing of importance is likely to come out of this conference. It may be that Empire lands like New Zealand, already worried about its tariff preferences, will learn that the British Government means to reduce those preferences still more.

The Government is more concerned with getting into the same trading system as Dr. Adenauer than with developing the Empire trading system.

Who supposes that Dr. Adenauer would give a fig for Europe if he had an Empire?

In this text the coder observed four discrete identity categories: imperial, Germany, Europe, and trading. He coded imperial as positive, with a note about the Empire/Commonwealth interchange in which New Zealand appears to be subsumed under the British Self. Germany and Europe were both significant Others. The former, epitomized in the figure of its chancellor, was negatively evaluated because its ambition (regional domination) and inferiority (no empire). The latter was merely neutral. Finally, though Britain was a trading nation, its aspiration was not free trade so much as "the Empire trading system." 44

Subjecting every texts in the Britain 1960 corpus to the same coding procedure the same coder then ran a tally of raw identity counts and their prevailing valence, first within texts and genres, and then across all five genres. ${ }^{45}$ In Figure 1, these two steps are represented as "contextualization" (Step 5) and “intertextualization" (Step 6).

Once all texts for 1960 were analyzed in this way, the coder prepared summary tables, from which he proceeded to Step 7: finding the prevailing British identity discourses in 1960. The goal here is to recover the fluid discursive "topography" or "terrain" of British identity in 1960 rather some fundamental aspect of Britishness in this or any other period of time. Consistent with constructivist teachings, this approach allows researchers to analyze national identity in a decidedly non-essentialist fashion. When taken forwards and backwards in time, this approach can and in fact does lead to a reconstruction of Britishness that captures not only the most layered elements of identity, but also its main complementarities and contrasts. ${ }^{46}$

Step 7 is the most theoretical in the sense that the coder clustered different identities categories into prevailing (hegemonic, dominant) and alternative (counter-hegemonic,

\footnotetext{
${ }^{44}$ Coding examples for each year under study are available on the project website.

45 The procedure might be called "interpretive quantification" in the sense that it adds to transparency, systematicity and cross-case comparability while respecting the fluidity and historically-constituted nature of intersubjective meanings. Barkin and Sjoberg 2017.

${ }^{46}$ This is similar to EN studies such as, for example, Skey 2011.
} 
subaltern) discourses according to the elite/mass divide, significant Others, and political, economic, social and cultural dimensions. Going back to the above example, while some discourses agreed that Britain was trading and imperial, others insisted that it was trading but post-imperial and a champion of decolonization everywhere, not just in so-called the British world. From this finding one can then draw hypotheses about how the prevailing sense of Britishness circa 1960 shaped British foreign policy understands at the time when U.S. Secretary State of State Dean Acheson publicly chided Britain for losing an Empire but not finding a role.

Therein lies one of the main contributions of MIC to IR. If we accept that the ideas and practices of "who we are" are always prior to "policy," then knowledge of national identity discourses can help us address a number of important research questions in this field: Which countries are likely to be deemed threats and which are likely to be labeled as friends or allies? Which international organizations, regimes and norms are useful or valid and which are neither? Which political, social and economic worldviews are shared across time and space, and which tend to be more idiosyncratic? What we wish to suggest below is that some of these questions might be of relevance to EN, and also to identify what these two approaches can borrow from each other, both in terms of analytic frames and in terms of methodology.

\section{Cross-fertilizations?}

The main motivation behind MIC is a desire to advance constructivist IR and practicetheoretic approaches to world politics. Scholars working in this tradition have already shown that national identity discourses, as part of domestic common sense, shape foreign policy decision-making and therefore international interaction. ${ }^{47}$ They do so because they contain heuristic categories and concepts that structure policy dispositions. Constructivists have proposed two causal mechanism: first, decision-makers are citizens, which makes them more likely to deploy common sense identity in constructing their own beliefs about international politics. Second, widely shared domestic identities constrain and enable policy-makers by making some policies more natural or easier to justify in public than others. This mechanism is known as "discursive fit": policy-makers will find it easier to marshal domestic support for foreign policy when that policy is taken-for-granted or otherwise acceptable in identity terms for both elites and masses. ${ }^{48}$ Crucially, this has been found to hold true even in authoritarian regimes as well because no leader, not even a Stalin-like figure, could consistently adopt policies that do not appeal to their "selectorates" and publics. ${ }^{49}$

MIC data will likely spur additional studies in this vein, not just of specific foreign policy decisions, but also of the co-evolution of national identities and foreign policies-how postwar Britain and France negotiated their "global" foreign policies at home and abroad, for example. While research in this tradition typically revolves around one and two states, our project shows

\footnotetext{
${ }^{47}$ For the most recent overviews, see Vucetic 2017 and Vucetic 2018.

${ }^{48}$ Constructivist IR scholars have long been preoccupied with the issue of discursive fit or resonance. Inter alia: Cortell and Davis 1996, Checkel 1999, Risse and Ropp 1999, Vucetic 2011.

${ }^{49}$ Hopf 2002.
} 
that this can be scaled up to the level of the system of states, thus addressing more theoretical debates in IR. One example is the rise of China and the future of international orders in Asia and the world. ${ }^{50} \mathrm{~A}$ thin ideological hegemony at the international level would be one that appeals to elites. A more enduring and comprehensive, or thick hegemony, would be one that is accepted as commonsensical by masses as well. If MIC analysis shows that "democracy" is what makes sense to both elites and masses across different countries, then we can conclude that China's bid for hegemony is unlikely to be successful. Along the same lines but looking at the literature on "pop culture and world politics," MIC research could be used to determine which pop culture aspects of global daily life are in fact global. ${ }^{51}$

Our wager from the outset has been that MIC research has a potential to contribute to, and cross-fertilize with, research programs in fields other than IR. ${ }^{52} \mathrm{EN}$ is a good candidate for this, but within limits given that MIC remains more narrowly focused on the biggest of "big nationalisms" - the nationalism of states as opposed to smaller groups or territories. ${ }^{53}$ This is to say that while MIC researchers can provide some insights about how particular national common sense intersects with social identities (race or gender, for example) or with the lived experiences of actors at individual and organizational scales (those in history classrooms, for example), their primary goal is always to generate knowledge for studying large-scale social and political processes involving national imagination and articulation. ${ }^{54}$

That said, MIC could potentially make both theoretical and methodological contributions to EN. One is the introduction of the aforementioned neo-Gramscian framework for analyzing the production of everyday nationalism. If Gramsci is correct, the greater the elite-mass agreement on boundaries between nationals and non-nationals, the more stable the idea of the world as a world of nations with fixed boundaries and hierarchies of belonging. Disagreement, in turn, would imply that such boundary-making is either elite or mass-driven, and so that the hegemony of nationhood is far more unstable and context-dependent than many think. Related, and following the work of Stuart Hall, it could also be that identity metamorphosis is only possible if material and symbolic resources are concentrated. ${ }^{55}$ But if national identity discourses are indeed rooted in what Gramsci calls "fragmentary, incoherent and inconsequential" practices of everyday life-and those most unselfconscious, taken-for-granted habits in particular - , then any attempted change, however concentrated and intentional, will be slow and uncertain. ${ }^{56}$ All of these competing hypotheses are of relevance to EN.

\footnotetext{
50 Allan, Vucetic, and Hopf 2018.

51 Inter alia: Nexon and Neumann, eds. 2006, Grayson, Davies, and Philpott 2009, and Furman and Musgrave 2017.

52 On how MIC data can travel beyond IR, see Vucetic 2016.

53 Todorova 2015: 687. On dealing with the pitfalls of methodological nationalism, see, inter alia, Ibid.: 686, 688, Thelen, Vetters, and von Benda-Beckmann 2014.

${ }^{54}$ Some theoretical limitations are of course shared: state-centrism, audience homogenization, lack of a truly global perspective, and under-theorization of noticed/unnoticed distinction. See Skey and Antonsich, eds. 2017, and especially the chapter by Spasić.

55 Hall 1996.

${ }^{56}$ On the social-theoretic, social-scientific and neuro-scientific underpinnings of the force of habit, see Hopf 2017.
} 
MIC analyses, too, can be of interest to EN scholars working on the relationship between elite constructions of national identity and ordinary people's understandings of it. Suppose one is interested in the "vertical" consistency of ideologically nationalist interpretations of British politics and society or in how people in Britain draw on the symbolic repertoires of Britishness, Englishness, Scottishness and other identities to create and express the terms of their relationships with other people with or against whom they identify. The most comprehensive way to examine these questions would be to follow what David McCrone and Frank Bechhofer have done and combine social attitudes survey research with ethnographies and in-depth interviews in multiple locales, notably including Berwick-on-Tweed and nearby sites on either side of the Scottish-English border. ${ }^{57}$ However, this sophisticated multi-level and multimethodology undertaking reaches back only to the 1990 s or even to 2001 , if one follows the surveys alone.

What the current installment of MIC offers is data and analysis from 1950 onwards. Though based only on discourse analysis, MIC's "British national identity reports" still provide valuable information on the changing meanings of key categories of national identification. An equivalent series of reports on Scottish national identity would enable within-UK comparisons, and together they would allow the researcher to make better sense of identity change over time. This would enable analyses not only of the New Labour-era constitutional reforms, which has been of particular interest to scholars such as Bechhofer and McCrone, but also of decolonization, wars, recessions, generational turnovers and other transformations in postwar British history. ${ }^{58}$ Given that scholars since at least Gellner have focused on the connections between nationalism and change, the potential usefulness of said data and analysis is evident.

MIC data on the content and contestation of national identities over time and space is likely to be valuable for mapping out the most salient identity categories available to elites and/or masses, their prevailing valences, and therefore about the conditions under which some national identity claims are likely to resonate with citizens while others do not. In this way, MIC might come to support Bart Bonikowski's call for a more reflexive use of survey research, as in his study of similarities and differences in the cultural repertoires of French and German nationhood. ${ }^{59}$ Such maps can then be mobilized to examine their cultural taproots of policy choices and political preferences, whether toward other states, as in IR, or toward immigration and economic protectionism, as in Bonikowski's work in the EN tradition. What is more, given that MIC analysts abstract their findings into nominal categories that can be counted, our project can also be of some interest to researchers who rely on survey research-the 1995, 2003 and 2013 ISSP National Identity modules or from the World Values Survey, for examplebut who wish to develop and deploy new typologies of nationhood rather than stick with hackneyed binaries, à la ethnic vs. civic.

\footnotetext{
${ }^{57}$ McCrone and Bechhofer 2005, esp. 33-42.

58 IR theorists are indeed primarily interested in regime changes, revolutions, military defeats, natural catastrophes (and similar chance events), world-level power transitions and other similar large-scale events and processes as a way of analyzing change. See, inter alia, Thies and Nieman 2017; Rumelili and Todd 2017; and Hopf 2018. On the value of comparisons in interpretivism, see Yanow 2014.

59 Bonikowski 2017.
} 
Going in the opposite direction, EN has already influenced MIC by heightening our theoretical attentiveness to the public/private and conscious/subconscious aspects of mass common sense. The results of Goode's research on Russian patriotism in 2014-15 show nontrivial inconsistencies in how the boundaries of nationhood are negotiated when one controls for "publicity," that is, when Russians talk about Russia in interviews versus in focus groups. ${ }^{60}$ In future research we intend to pursue a similar research strategy to determine the degree to which privately held views about the nation differ from those expressed in texts. A finding that this difference is consistently large across contexts would be valuable for theoretical reasons, starting with our interest in the neo-Gramscian theories of hegemony. It would be valuable for methodological reasons as well, since "talking to people about the nation"-as in the aforementioned studies by McCrone and Bechhofer and by Goode-would provide an opportunity for a validity check on MIC analyses, at least those conducted in more contemporary time. As Michael Skey has argued in his study of contemporary Englishness and Britishness, interviews can be exceptionally helpful in accessing, through deixis and other forms of everyday talk, those commonsensical understandings of territoriality, temporality and political organization that are of interest to both MIC and EN researchers. ${ }^{61}$

As they endeavor to expand their data base backwards in time, MIC researchers will borrow EN insights on the importance of making one's data sources less print-centric. A good starting point in this regard is Edensor's conceptualization of the nation as a "matrix" that encompasses everything from material and visual environments to cultural performances to eating habits. ${ }^{62}$ MIC's inductive approach is in principle well suited for the analysis of objects such as coins and stamps, airports, railways, and other aspects of built environment as well as memorial structures such as museums or cemeteries. The challenge, then, is to identify such objects and analyze them with the right techniques in a way that stays true to the project's methodological "first principles" and also captures the fluid and historically-constituted character of the nationas-matrix.

\section{Conclusion}

We have identified a number of conceptual and methodological complementarities between EN and our Gramsci-inspired project on national identity. Said complementarities point several areas of potential cross-fertilization. We have argued that MIC brings to the EN scholarship a new method for uncovering national identity discourses from everyday texts, for cross-national and over time comparisons, and for better design of surveys and other instruments for recovering identity. On the other side, what EN brings to MIC are new theoretical and methodological tools for identify the unnoticed aspects of mass common sense as well as for moving away from discourse and print-centrism. Studies in the former tradition have indeed demonstrated that it is possible to unearth national identity discourses, contemporary as well as historical, from various material, spatial, and performative dimensions of nationhood. This

\footnotetext{
60 Goode 2017.

${ }^{61}$ Skey 2011. Also see Fox and Miller-Idris 2008, p. 540, and Billig 1996: 61.

62 Edensor 2002. Also see Fox and Miller-Idris 2008, Sumartojo 2013 and Skey and Antonsich, eds, 2017.
} 
literature holds significant promise for MIC future research. While cross-fertilization calls have a tendency to minimize nuances, limitations and challenges, we do think that the issues profiled here represent the beginning of a larger and more sustained dialogue between EN and MIC, and ways in which it could help open up new research avenues. 
Table 1 Textual Sources of British National Identity, 1950-2000

\begin{tabular}{|c|c|c|c|c|c|}
\hline Year & Speeches & Newspapers & Textbooks & Films & Novels \\
\hline \multirow[t]{2}{*}{$\begin{array}{l}1950 \\
(\text { Lab) }\end{array}$} & $\begin{array}{l}\text { Attlee. The King's Speech, } \\
\text { 1.3. }\end{array}$ & Daily Express & Carter \& Mears. History of Britain. & The Blue Lamp & Christie. A Murder Is Announced \\
\hline & $\begin{array}{l}\text { Attlee. Margate, } \\
3.10 .\end{array}$ & Daily Mirror & Rayner. Short History of Britain & $\begin{array}{l}\text { What the Butler } \\
\text { Saw }\end{array}$ & Shute. A Town Like Alice \\
\hline \multirow[t]{2}{*}{$\begin{array}{l}1960 \\
\text { (Cons) }\end{array}$} & $\begin{array}{l}\text { Macmillan. Scarborough, } \\
15.10 .\end{array}$ & Daily Express & $\begin{array}{l}\text { Barker \& Ollard. General History of } \\
\text { England }\end{array}$ & Doctor in Love & Fleming. $\mathrm{Dr} N o$ \\
\hline & $\begin{array}{l}\text { The Queen's Speech, } \\
\text { 1. } 11 .\end{array}$ & Daily Mirror & Strong. History of Britain \& the World & $\begin{array}{l}\text { Sink the } \\
\text { Bismarck! }\end{array}$ & Christie. 4.50 from Paddington \\
\hline \multirow[t]{2}{*}{$\begin{array}{l}1970 \\
\text { (both) }\end{array}$} & $\begin{array}{l}\text { Wilson. Debate on } \\
\text { Address } 2.6\end{array}$ & Daily Express & Titley. Machines, Money \& Men & $\begin{array}{l}\text { Her Majesty's } \\
\text { Secret Service }\end{array}$ & Christie. Endless Night \\
\hline & $\begin{array}{l}\text { Heath. Debate on Address } \\
\text { 2.6. }\end{array}$ & Daily Mirror & Larkin. English History & Battle for Britain & MacLean. Force 10 from Navarone \\
\hline \multirow[t]{2}{*}{$\begin{array}{l}1980 \\
\text { (Cons) }\end{array}$} & $\begin{array}{l}\text { Thatcher. Brighton. } \\
\text { 10.10. }\end{array}$ & Daily Express & Hill. British Eco and Soc History. & Life of Brian & Forsyth. The Devil's Alternate \\
\hline & $\begin{array}{l}\text { The Queen's Speech. } \\
\text { 7. } 11 .\end{array}$ & Daily Mirror & Sked \& Cook. Post-War Britain & McVicar & Smith. Wild Justice \\
\hline \multirow[t]{2}{*}{$\begin{array}{l}1990 \\
\text { (Cons) }\end{array}$} & $\begin{array}{l}\text { The Queen's Speech. } \\
\text { 7. } 11 .\end{array}$ & The Sun & Kavanagh \& Morris. Consensus Politics & Shirley Valentine & Forsyth. The Negotiator \\
\hline & $\begin{array}{l}\text { Major. 'First Speech', } \\
\text { 4. } 12 .\end{array}$ & Daily Mirror & $\begin{array}{l}\text { Connolly \& Barry. Britain 1900-1939 \& } \\
\text { May. Economic and Social History }\end{array}$ & The Krays & Smith. A Time to Die \\
\hline \multirow[t]{2}{*}{$\begin{array}{l}2000 \\
(\text { Lab) }\end{array}$} & $\begin{array}{l}\text { Blair. Brighton. } \\
26.9 .\end{array}$ & The Sun & Walsh. Modern World History. & Chicken Run & $\begin{array}{l}\text { Rowling. Harry Potter and the Goblet } \\
\text { of Fire }\end{array}$ \\
\hline & $\begin{array}{l}\text { Blair. 'Britain speech' } \\
\text { 28. } 3 .\end{array}$ & Daily Mail & $\begin{array}{l}\text { Culpin \& Turner. Making Modern } \\
\text { Britain }\end{array}$ & Billy Elliott & $\begin{array}{l}\text { Rowling. Harry Potter and the } \\
\text { Philosopher's Stone }\end{array}$ \\
\hline
\end{tabular}


Figure 1: Making Identity Count, From Theory to Findings

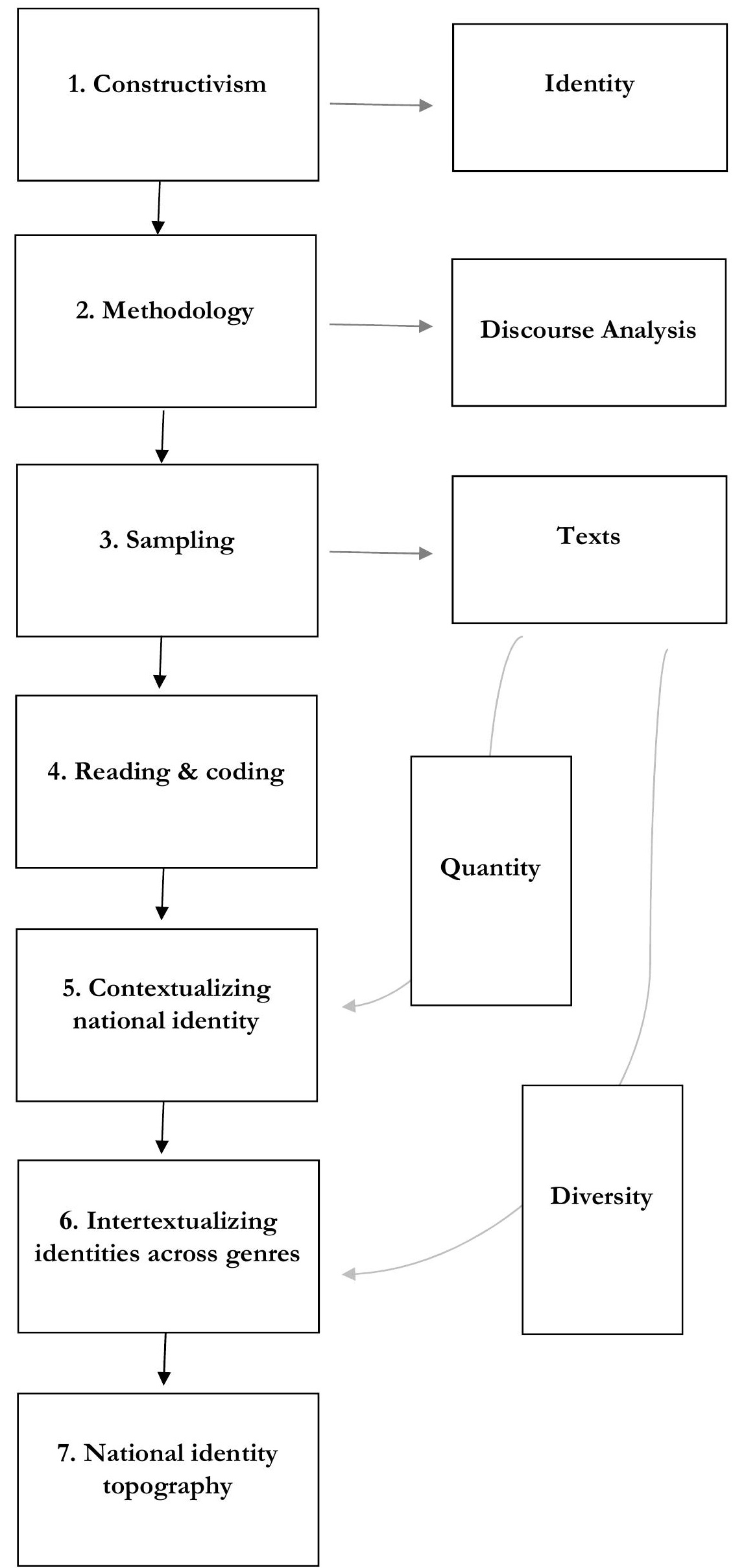




\section{Bibliography}

Abdelal, Rawi, Yoshiko Herrera, Alastair lain Johnston, and Rose McDermott, eds. 2009. Measuring Identity: A Guide for Social Scientists. Cambridge: Cambridge University Press.

Alemán, José and Dwayne Woods. 2017. "Inductive Constructivism and National Identities: Letting the Data Speak." Nations and Nationalism 24(4).

Allan, B. 2016. "Recovering Discourses of National Identity." In Making Identity Count: Building a National Identity Database, edited by Ted Hopf and Bentley B. Allan, 20-44. Oxford: Oxford University Press.

Allan, B, S Vucetic and T Hopf. 2018. "The Distribution of Identity and the Future of International Order: China's Hegemonic Prospects." International Organization 72(4): 839-869.

Barkin, J. Samuel and Laura Sjoberg, eds. 2017. Interpretive Quantification: Methodological Explorations for Critical and Constructivist IR. University of Michigan Press.

Billig, Michael. 1995. Banal Nationalism. London: Sage.

Billig, Michael. 2017. "Banal Nationalism and the Imagining of Politics," in Everyday Nationhood: Theorising Culture, Identity and Belonging after Banal Nationalism. Michael Skey and Marco Antonsich (eds). Palgrave, 307- 321

Bieler, Andreas, Ian Bruff and Adam David Morton. 2015. "Gramsci and 'the International': Past, Present and Future," in Antonio Gramsci, edited by Mark McNally, 137-155. Basingstoke: Palgrave.

Bonikowski, Bart. 2017. "Nationhood as Cultural Repertoire: Collective Identities and Political Attitudes in France and Germany." Everyday Nationhood: Theorising Culture, Identity and Belonging after Banal Nationalism, edited by Michael Skey and Marco Antonsich, 147-174. London, UK: Palgrave MacMillan.

Cortell, AP and J. Davis. 1996. How do international institutions matter? The domestic impact of international rules and norms. International Studies Quarterly 49: 451-478

Cox, Robert W. 1987. "Production, Power, and World Order: Social Forces in the Making of History." Columbia University Press.

Edensor, Tim. 2002. National Identity, Popular Culture and Everyday Life. London: Berg.

Checkel JT. 1999. Norms, institutions, and national identity in contemporary Europe. International Studies Quarterly 43: 84-114. 
Goode, J.P. and D.R. Stroup. 2015. "Everyday Nationalism: Constructivism for the Masses." Social Science Quarterly 96(3): 717-739.

Goode, J.P. 2017. Humming along: Public and private patriotism in Putin's Russia. In: Skey, M, Antonsich, M (eds) Everyday Nationhood: Theorising Culture, Identity and Belonging after Banal Nationalism. London: Palgrave Macmillan, pp.121-146.

Goswami, Manu. 2012. "Imaginary Futures and Colonial Internationalisms." American Historical Review 117(5): 1461-1485.

Gramsci, Antonio. 1929-35. Prison Notebooks, Vols 1-3 (1992, 1996, 2007), translated by Joseph A. Buttigieg (the first volume with Antonio Callari). New York: Columbia University Press.

Grayson, K, Davies, M, Philpott, S. 2009. Pop goes IR? Researching the popular culture-world politics continuum. Politics 29(3): 155-163.

Fox, J., \& Miller-Idriss, C. 2008. Everyday nationhood. Ethnicities, 8(4): 536-563.

Furman, Daniel, J. III and Musgrave, Paul. 2017. "Synthetic Experiences: How Popular Culture Matters for Images of International Relations," International Studies Quarterly 61(3): 503-16.

Hall, Stuart. 1996. Introduction: Who needs 'identity'? In Questions of Cultural Identity. S. Hall and P. duGay (eds), 1-17. London: Sage Publications,

Hopf, Ted. 2002. The Social Construction of International Politics. Ithaca: Cornell University Press.

Hopf, T. 2017. "Change in International Practices." European Journal of International Relations 24(3): 687-711.

Hopf, T. 2010. "The Logic of Habit in International Relations." European Journal of International Relations 16(4): 539-561.

Hopf, Ted. 2013. "Common-Sense Constructivism and Hegemony in World Politics." International Organization 67(2): 317-354.

Hopf, Ted, and Bentley B. Allan. 2016. Making Identity Count: Building a National Identity Database. Oxford: Oxford University Press.

Ichijo, Atsuko (2016) Nationalism, Everyday. In: Stone, John, Dennis, Rutledge M. , Rizova, Polly, Smith, Anthony D. and Hou, Xiaoshuo, (eds.) The Wiley Blackwell Encyclopedia of Race, Ethnicity, and Nationalism. Wiley Blackwell, at www.raceethnicitynationalism.com 
Knott, Eleanor. 2015. "Everyday Nationalism: A Review of the Literature." Studies on National Movements 3: 1-6.

Malešević, Siniša. 2013. Nation-States and Nationalisms: Organization, Ideology and Solidarity. Cambridge: Polity.

McCrone, David and Frank Bechhofer. 2015. Understanding National Identity. Cambridge: Cambridge University Press.

Morozov, Viacheslav and Elena Pavlova. 2020. "Popular culture and authoritarianism in Russia: A study of common sense through the prism of women's fiction," Europe-Asia Studies, TBD

Nexon, Daniel H. and Iver B. Neumann, eds. Harry Potter and international relations. Lanham, MD: Rowman \& Littlefield, 2006.

Rabaka, Reiland. 2009. Africana Critical Theory: Reconstructing the Black Radical Tradition, from W. E. B. Du Bois and C. L. R. James to Frantz Fanon and Amilcar Cabral. New York: Lexington Books.

Risse T and Ropp SC. 1999. International human right norms and domestic change: Conclusions. In: Risse T, Ropp SC and Sikkink K (eds) The Power of Human Rights: International Norms and Domestic Change. Cambridge: Cambridge University Press, pp. 234-278.

Rumelili, Bahar, and Jennifer Todd. 2017. "Paradoxes of Identity Change: Integrating Macro, Meso, and Micro Research on Identity in Conflict Processes." Politics 38(1): 3-17.

Smith, Rogers. 2015. Political Peoplehood: The Roles of Values, Ideas, and Identities. Chicago: University of Chicago Press.

Skey, M. and M. Antonisch, eds. 2017. Everyday Nationhood: Theorising Culture, Identity and Belonging After Banal Nationalism. London: Palgrave Macmillan.

Skey, M. 2009. "The national in everyday life: A critical engagement with Michael Billig's thesis of Banal Nationalism." The Sociological Review, 57(2), 331-345.

Skey, M. 2011. National Belonging and Everyday Life. Basingstoke: Palgrave.

Spasić, Ivana 2017. "The universality of banal nationalism, or, Can the flag hang unobtrusively outside a Serbian post office?" In M Skey \& M Antonsich, eds. Everyday Nationhood: Theorising Culture, Identity \& Belonging After Banal Nationalism. Basingstoke: Palgrave, pp. 31-51.

Sumartojo, S. 2013. "The fourth plinth: Creating and contesting national identity in Trafalgar Square, 2005-2010," Cultural Geographies, 20, 67-81. 
Thies, Cameron G. and Mark David Nieman. 2017. Rising Powers and Foreign Policy Revisionism: Understanding BRICS Identity and Behavior Through Time. Ann Arbor: University of Michigan Press.

Thelen, Tatjana Larissa Vetters, and Keebet von Benda-Beckmann. 2014. "Introduction to Stategraphy: Toward a Relational Anthropology of the State," Social Analysis 58 (1): 1-19.

Todorova, Maria. 2015. "Is There Weak Nationalism and Is It a Useful Category?" Nations and Nationalism 21(4): 681-699.

Vucetic, S. 2011. The Anglosphere: A Genealogy of a Racialized Identity in International Relations. Stanford: Stanford University Press.

Vucetic, S. 2016. “Making It Count Beyond IR." In Making Identity Count: Towards a National Identity Database edited by Ted Hopf and Bentley Allan. 201-218. Oxford: University of Oxford Press.

Vucetic, S. 2017. "Identity and Foreign Policy." Oxford Research Encyclopedia of Politics. At https://oxfordre.com/politics/view/10.1093/

Vucetic, S. 2018. "Identity and Foreign Policy." In Oxford Bibliographies in International Relations, edited by Patrick James. New York: Oxford University Press.

Vucetic, S. 2019. "America in 'British' Textbooks," In Culture matters: Anglo-American relations and the intangibles of 'specialness', edited by Steve Marsh and Robert M. Hendershot, TBD, Manchester: Manchester University Press

Wæver, O. 1996. "European Security Identities." Journal of Common Market Studies 34(1): 103132.

Yanow, Dvora. 2014. "Interpretive Analysis and Comparative Research." In Comparative Policy Studies: Conceptual and Methodological Challenges, edited by Isabelle Engeli and Christine Rothmayr Allison, 131-159. New York: Palgrave Macmillan. 